position, public procurement, mergers and state aid; EFTA to create an EFTA Surveillance Authority and an EFTA Court; individuals to be free to live, work and offer services throughout the EEA, with mutual recognition of professional qualifications; capital movements to be free with some restrictions on investments; EFTA countries not to be bound by the Common Agricultural Policy (CAP) or Common Fisheries Policy (CFP).

The EEA-EFTA states have established a Surveillance Authority and a Court to ensure implementation of the Agreement among the EFTA-EEA states. Political direction is given by the EEA Council which meets twice a year at ministerial level, while ongoing operation of the Agreement is overseen by the EEA Joint Committee. Legislative power remains with national governments and parliaments.

EFTA has formal relations with several other states. Declarations on co-operation were signed with Hungary, former Czechoslovakia and Poland (1990), Bulgaria, Estonia, Latvia, Lithuania and Romania (1991), Slovenia and Albania (1992), Egypt, Morocco and Tunisia (1995), the former Yugoslav Republic of Macedonia and the Palestine Liberation Organization (1996), Jordan and Lebanon (1997), Croatia, the Gulf Co-operation Council, Serbia (as Serbia and Montenegro until 2006), MERCOSUR and Ukraine (2000), Algeria (2002) and Peru and Colombia (2006). Free trade agreements have been signed with Turkey (1991), Israel and Czechoslovakia (1992, with protocols on succession with the Czech Republic and Slovakia in 1993), Poland and Romania (1992), Bulgaria and Hungary (1993), Estonia, Latvia, Lithuania and Slovenia (1995), Morocco (1997), the Former Yugoslav Republic of Macedonia and Mexico (2000), Jordan and Croatia (2001), Singapore (2002), Chile (2003), Lebanon and Tunisia (2004), South Korea (2005) and the Southern African Customs Union (2006). In Dec. 1998 an interim free trade agreement was signed with the Palestinian Authority and talks on an agreement began with Egypt. Negotiations on free trade agreements are ongoing with Canada, Egypt, the Gulf Co-operation Council and Thailand.

Organization. The operation of the free trade area among the EFTA states is the responsibility of the EFTA Council which meets regularly at ambassadorial level in Geneva. The Council is assisted by a Secretariat and standing committees. Each EFTA country holds the chairmanship of the Council for six months. For EEA matters there is a separate committee structure.

Brussels Office (EEA matters, press and information): 12-16 Rue Joseph II, B-1000 Brussels.

Headquarters: 9-11 rue de Varembé, 1211 Geneva 20,

Switzerland.

Website: http://www.efta.int

e-mail: efta-mailbox@secrbru.efta.be

Secretary-General: Kåre Bryn (Norway).

Publications. Convention Establishing the European Free Trade Association; EFTA Annual Report; EFTA Fact Sheets: Information Papers on Aspects of the EEA; EFTA Bulletin.

\section{European Space Agency (ESA)}

History. Established in 1975, replacing the European Space Research Organization (ESRO) and the European Launcher Development Organization (ELDO).

Members. Austria, Belgium, Denmark, Finland, France, Germany, Greece, Ireland, Italy, Luxembourg, the Netherlands, Norway, Portugal, Spain, Sweden, Switzerland, United Kingdom. Canada takes part in some projects under a co-operation agreement.
Activities. ESA is the intergovernmental agency in Europe responsible for the exploitation of space science, research and technology for exclusively peaceful purposes. Its aim is to define and put into effect a long-term European space policy that allows Europe to remain competitive in the field of space technology. It has a policy of co-operation with various partners on the basis that pooling resources and sharing work will boost the effectiveness of its programmes. Its space plan covers the fields of science, Earth observation, telecommunications, navigation, space segment technologies, ground infrastructures, space transport systems and microgravity research.

\author{
Headquarters: 8-10 rue Mario Nikis, 75738 Paris Cedex 15, \\ France. \\ Website: http://www.esa.int \\ Director-General: Jean-Jacques Dordain (France).
}

\section{CERN - The European Organization for Nuclear Research}

Founded in 1954, CERN is the world's leading particle physics research centre. By studying the behaviour of nature's fundamental particles, CERN aims to find out what our Universe is made of and how it works. CERN's biggest accelerator, the Large Hadron Collider (LHC), is scheduled to become operational in late 2007. One of the beneficial byproducts of CERN activity is the Worldwide Web, developed at CERN to give particle physicists easy access to shared data. One of Europe's first joint ventures, CERN now has a membership of 20 member states: Austria, Belgium, Bulgaria, Czech Republic, Denmark, Finland, France, Germany, Greece, Hungary, Italy, the Netherlands, Norway, Poland, Portugal, Slovak Republic, Spain, Sweden, Switzerland, United Kingdom. Some 6,500 scientists, half of the world's particle physicists, use CERN's facilities. They represent 500 institutions and 85 nationalities.

Address: CH-1211 Geneva 23, Switzerland.

Website: http://www.cern.ch

Director-General: Dr Robert Aymar (France).

\section{Central European Initiative (CEI)}

In Nov. 1989 Austria, Hungary, Italy and Yugoslavia met on Italy's initiative to form an economic and political co-operation group in the region.

Members. Albania, Austria, Belarus, Bosnia-Herzegovina, Bulgaria, Croatia, Czech Republic, Hungary, Italy, Macedonia, Moldova, Montenegro, Poland, Romania, Serbia, Slovakia, Slovenia, Ukraine.

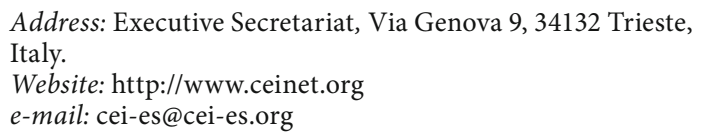

\section{Nordic Council}

Founded in 1952 as a co-operative link between the parliaments and governments of the Nordic states. The co-operation focuses 